Historic, Archive Document

Do not assume content reflects current scientific knowledge, policies, or practices. 



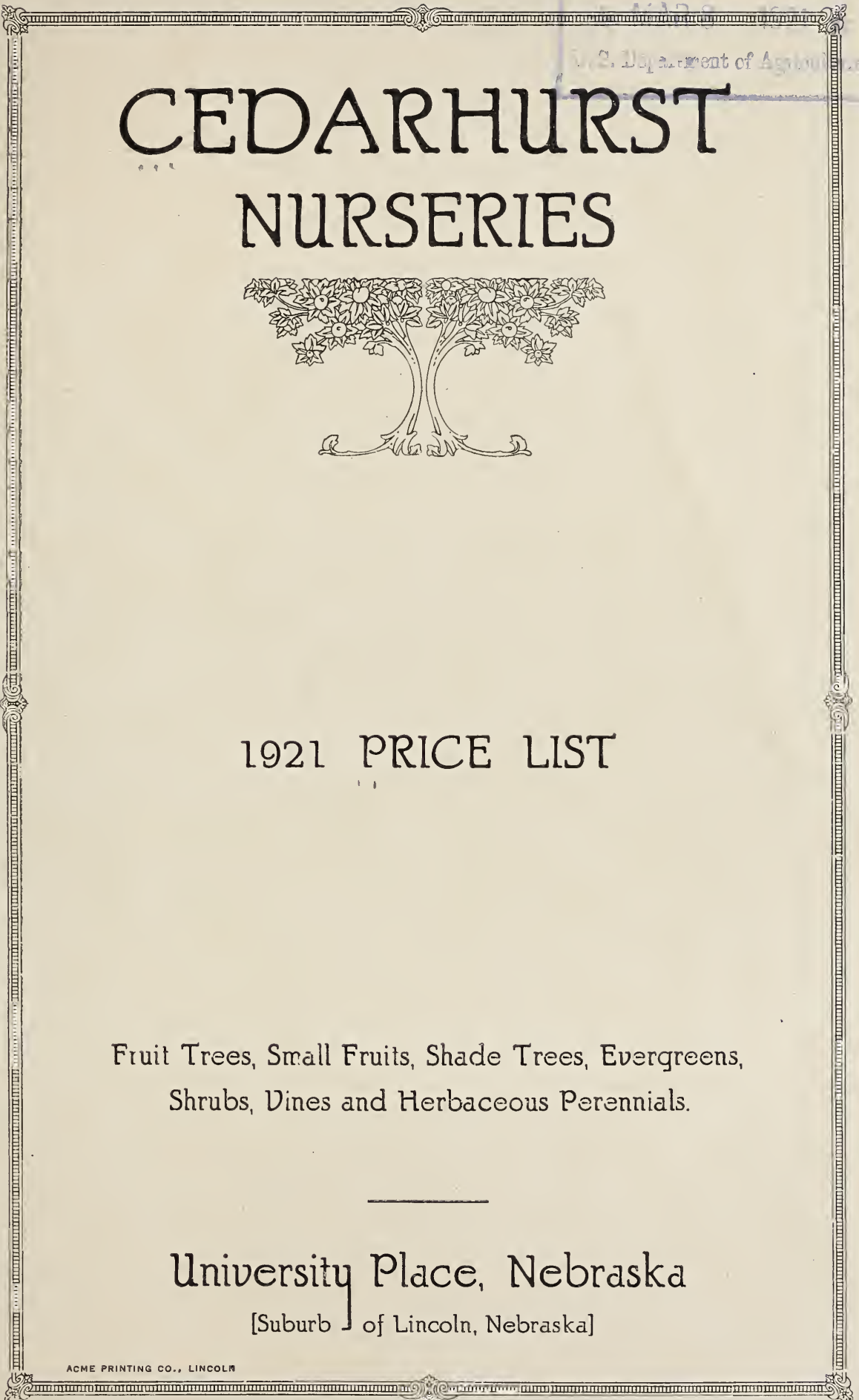





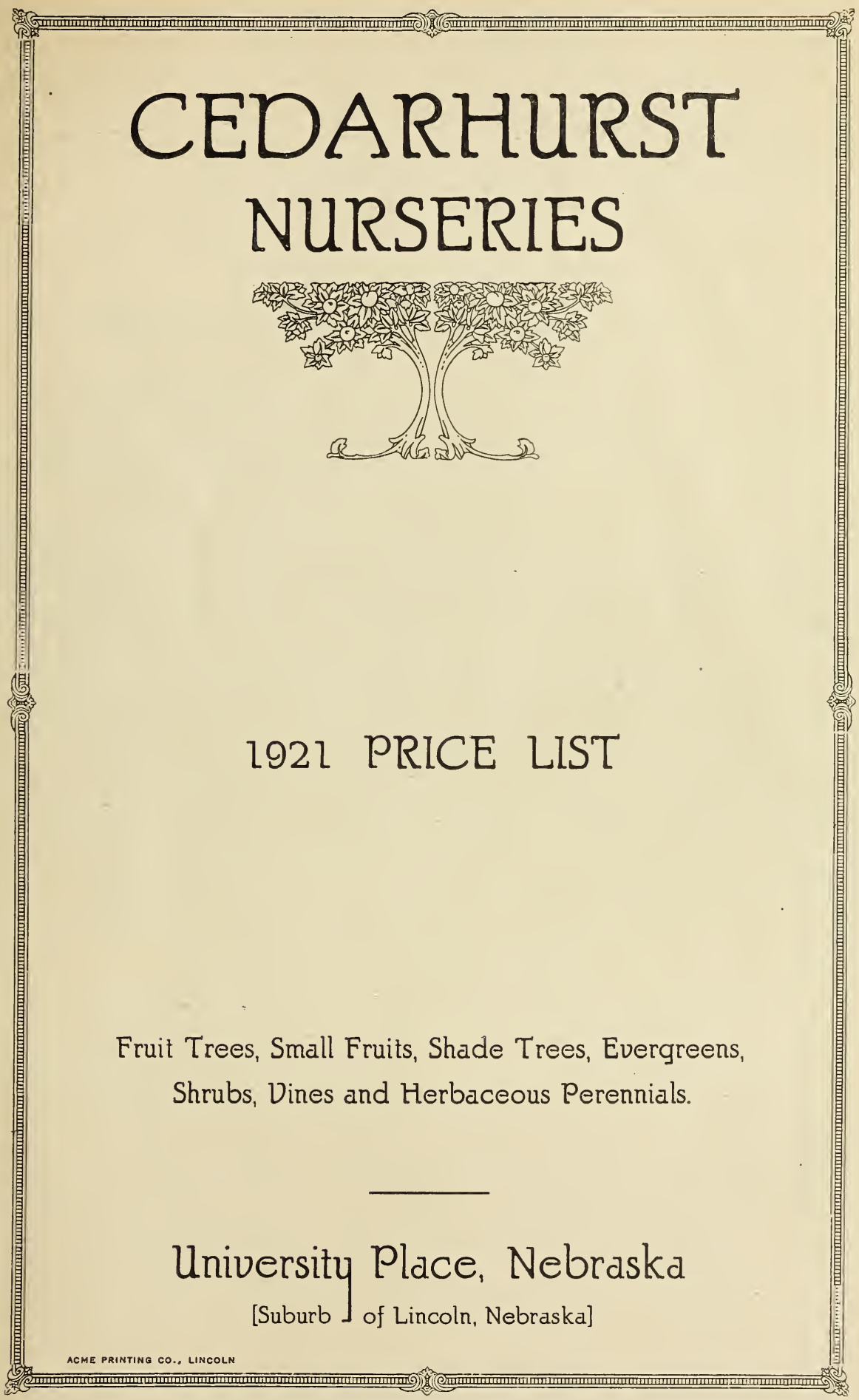




\section{The Cedarhurst Nurseries.}

The Cedarhurst Nurseries, formerly the Home Nursery, L. O. Williams, proprietor, are now owned and managed by A. P. and H. F. Herminghaus.

The Nurseries are located at University Place, Nebr., (suburb of Lincoln) and can be reached by both the Lincoln Traction Co., and Interurban lines.

Stock will be supplied at the prices named herein as follows: Five of any one variety at the ten rate; twenty-five of any one rariety at the hundred rate:

We give no warranty, expressed or implied as to quality, description, productireness, or any other matter of any nursery stock that we sell.

Tre do not guarantee our stock to live and no allowance will be made for goods that fail to live after being planted. Our methods of handling and packing stock are up to date and goods will be in good condition when they leave our grounds. Our responsibility ends upon delivery to carriers. If goods suffer through delay in transit, claim should at once be made on the transportation company.

All claims for errors must be made within six days after receipt of goods, or they will not be considered.

We do not do a credit business. All orders must be accompanied by remittance. Exchange must be added to personal checks.

All goods shipped by express collect unless otherwise instructed.

We will be equipped to do planting, within the delivery limits of Lincoln, at the following prices:

Trees not over ten feet,

Each

Evergreens not over 5 feet

Shrubs Each

HEDGES-

Per 100

Russian Mulberry

Privet

Barberry, 12 to 18 inches

10.00

Barberry 2 to 3 feet.

15.00

Lilac and Spirea

Spruce and Cedar. 


\section{FRUIT TREES}

APPLES, Standard, first class..........................5 to 6 feet
SUMMER VARIETIES
DUCHESS, EARLY HARVEST, RED ASTRACHAN, RED JUNE, 'YELLOW TRANSPARENT.

\section{AUTUM VARIETIES}

WEALTHY, MAIDEN BLUSH, TALMAN SWEET

\section{WINTER VARIETIES}

JONATHAN, GRIMES GOLDEN, WINESAP, DELICIOUS, GANO, N. W. GREENING.

If you intend to plant but one apple in Nebraska, plant a Jonathan. It is very productive and comparatively free from injurious pests. We also recommend that you plant the Duchess for your summer apple and the Wealthy for the fall.

CRAB APPLES, Florence, Whitney, Minnesota, first

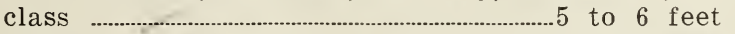

APRICOTS, J. L. Budd.................................5 to 6 feet

Each

Per 10

Per 100

$\$ 1.00$

$\$ 9.00$

$\$ 80.00$

CHERRIES, Early Richmond, Late Montmorency, Eng-

lish Morello 5 to 6 feet

80.00

COMPASS CHERRY PLUM, a wonderfully hardy and prolific fruit resembling both the cherry and plum. Valuable for canning and preserving ................................................................... 4 to 5 feet

PEACHES, Champion, Crosby, Heath Cling, Elberta 4 to $5 \mathrm{ft}$.

PEARS, Kieferer, Flemish Beauty, Duchess (Dwarf), Duchess 5 to 6 feet

PLUMS, Forest Garden, Terry, Opata, Wild Goose, CWyant, ISurprise, Shrop- Damson.......4 to 6 feet

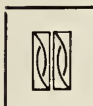

\section{SMALL FRUITS}

Per 10 $\$ 1.00$

CURRANTS, Perfection, 2-year, No. 1.-. $1 . \mathbf{3 . 5 0}$

Per 100

RASPBERRIES, St. Regis (red), King (red), Cumberland (black)

STRAWBERRIES, Senator Dunlap, Brandywine Per 25 Progressive (Everbearing)

9.00

Per 100

2.00

4.00

Per 100

$\$ 30.00$

35.00

35.00

35.00

2.00

4.00

15.00

Per 10

30.00

Per 100

.80 
Evergreens are a specialty with us and our collection includes only those varieties which are adapted to the Middle-West. We transplant and root prune our Evergreens frequently which practically insures their successful transplanting, even the larger specimens.

All the larger specimens are balled and baled.

Spruces and Cedars for hedges will not be balled and baled.

Common and Botanical Names

Each Per 10

Per 100

ARBORVITAE, AMERICAN (Thuja Occidentalis)

12 to 18 inches

18 to 24 inches

$\$ 1.00$

1.50

2 to 3 feet

$\$ 8.00$
12.00
17.50

This tree should be planted where it will have some protection, i. e., on the north side of buildings or trees. Not recommended for open planting.

ARBORVITAE; SIBERIAN (Thuja Occidentalis Siberica)

12 to 18 inches

18 to 24 inches 1.50 8.00 12.00

Somewhat more hardy than the American.

WHITE FIR (Abies Concolor)

2 to 3 feet

3 to 4 feet 4.00 37.50

A beautiful Fir of rapid growth and stands exposure to heat and drouth.

JUNIPER, PROSTRATE, $1 \frac{1 / 2}{2}$ to 2 feet 3.00

A low prostraet evergreen shrub attaining a height of two feet. An excellent evergreen for foundation planting, especially on the north side, also very picturesque when planted in vases.

JUNIPER, IRISH (Juniperus communis Hibernica)

18 to 24 inches

2 to 3 feet

14.00 22.50

Pyramidal in form and of striking silvery foliage, but very short lived, from seven to ten years.

\section{Common and Botanical Names}

Each

Per 10

Per 100

JUNIPER, RED CEDAR (Juniperus Virginiana)

12 to 18 inches

2 to 3 feet

3 to 4 feet

5.00

4 to

5 feet

10.00

6 to 8 feet

20.00

$\$ 6.75$

$\$ 60.00$

The best all around evergreen for Nebraska. Well adapted to trimming, especially when used for hedging.

JUNIPER, COLORADO SILVER CEDAR (Junipus Scopulorum )

2 to 3 feet

3 to 4 feet

This is the silver form of the common red cedar. During winter it retains its silver color whereas the red turns brown. 


\section{EVERGREENS-Continued}

JUNIPER, SAVIN (Juniperus Sabina)

18 to 24 inches

2 to 3 feet

A low spreading, dark green evergreen.

PINE AUSTRIAN (Pinus austriaca)

Each

2 to 3 feet

3 to 4 feet

4 to 5 feet

5 to 6 feet

6 to 8 feet

Very rapid growth and of pleasing color.

PINE, BULL (Pinus ponderosa)

2 to 3 feet

3 to 4 feet

4 to 5 feet

5 to 6 feet

.50 to

10.00 to

6 to 8 feet

3.00

5.00

Native of Nebraska. Very similar to Austian.

10.00

15.0(

30.00

PINE, MUGHO ( Pinus momtana mughus)

12 to 18 inches

18 to 24 inches

24 to 30 inches

A dwarf pine which does well in almost any dry soil.

PINE, SCOTCH (Pinus Sylvestris)

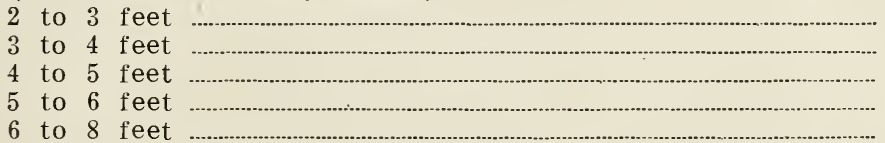

7.50 to

Common and Botanical Names

Each

PINE WHITE (Pinus strobus)

2 to 3 feet

3 to 4 feet

4 to 5 feet

5.00

5 to 6 feet

10.00

6 to 8 feet

7.50 to

15.00

An excellent Pine but somewhat difficult to start.

SPRUCE, COLORADO BLUE (Picea pungens glauca)

2 to 3 feet

3 to 4 feet

A popular blue Evergreen, very hardy and thifty.

SPRUCE, KOSTERS BLUE (Picea pungens kosteriana)

2 to 3 feet

3 to 4 feet in color.

The most popular of all the Spruces. Steel blue

SPRUCE, DOUGLAS' (Pseudotsuga taxifolia)

2 to 3 feet

- One of the largest and most rapid growing Spruces.

SPRUCE, NORWAY (Picea excelsa)
2 to 3 feet
3 to 4 feet
4 to 5 feet
Grows rapidly and makes a fine specimen, valuable for wind breaks and hedges. 


\section{EVERGREENS-Continued}

SPRUCE, WHITE (Picea alba)
18 to 24 inches
1.00
2 to 3 feet
5.00
4 feet
10.00
4 to 5 feet
15.00

9.00

80.00

-............

A native Spruce that resembles a Norway Spruce, excepting that it is more compact and a slower grower. Especially adapted for low trimmed hedges. Same thing as Black Hills Spruce.

\section{TREES}

Common and Botanical Names Each Per 10 Per 100

ASH, AMERICAN WHITE (Fraxinus American)

6 to 8 feet

$\$ 1.25 \$ \$ 10.00$

8 to 10 feet

$1.50 \quad 12.50$

ASH, EUROPEAN MOUNTAIN (Sorbus Aucuparia)

6 to 8 feet

8 to 10 feet

ASH, OAK LEAF MOUNTAIN (Sorbus Quercifolia)

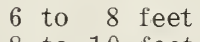

8 to 10 feet

BIRCH, EUROPEAN WHITE (Betula alba)

6 to 8 feet

8 to 10 feet

12.50

17.50

BIRCH, CUT-LEAF WEEPING (Betula alba pendula laciniata)

6 to 8 feet

8 to 10 feet

CATALPA, CHINESE (Bungeii)

5 to 6 feet

6 to 8 feet

CATALPA, WESTERN (Speciosa)

6 to 8 feet

BIRD CHERRY (Prunus Padus)

6 to 8 feet

A small flowering tree, very beautiful as a specimen.

CRAB, BECHTEls DOUBLE FLOWERING (Pyrus Ioensis Bechteli)

2 to 3 feet

3 to 4 feet

4 to 5 feet

Common and Botanical Names

CRABAPPLE, FLOWERING (Pyrus floribunda,)

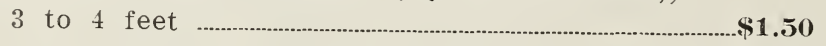

CRABAPPLE, WILD (Pyrus coronaria) 4 to 5 feet.... 2.00 
CRABAPPLE, WHITNEY, 5 to 6 feet...

A small pyramidal tree, an excellent substitute for

the Lombardy Poplar.

ELM, AMERICAN WHITE (Ulmus Americana)

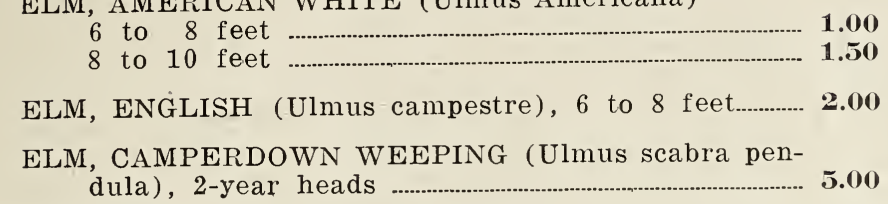

HACKBERRY (Celtis occidentalis)

$$
\begin{aligned}
& 6 \text { to } 8 \text { feet } \\
& 8 \text { to } 10 \text { feet }
\end{aligned}
$$

HOP-TREE (Ptelea trifoliata), 5 to 6 feet

LINDEN, AMERICAN (Tilia americana)

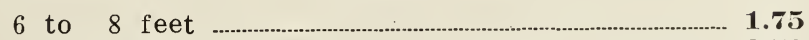

8 to 10 feet ...................................................................................

One of the finest street and ornamental trees.

LOCUST, HONEY (Gleditschia triacanthos)

6 to 8 feet

. 8 to 10 feet

MAPLES SUGAR (Acer saccharum) 4 to 5 feet.

MAPLE, NORWAY (Acer platanoides) 4 to 5 feet.......... 1.50 Common and Botanical Names Each

MAPLE, SOFT (Acer Dasycarpum)
6 to 8 feet

8 to 10 feet

MAPLE, CUT LEAF (Acer Dasycarpum Wierii)

10 to 12 feet

MAPLE, SIBERIAN (Acer Tartaricum Ginnala)

$$
4 \text { to } 5 \text { feet }
$$

MULBERRY, TEAS WEEPING (Morus Tartarica Pendula), 2-year heads

OAK, SCARLET (Quercus coccinea)

4 to 6 feet

6 to 8 feet

8 to 10 feet

OAK, PIN (Quercus palustris)

6 to 8 feet 2.50

8 to 10 feet

OAK, BURR (Quercus Macrocarpa) 6 to 8 feet. 2.50

OAK, RED (Quercus rubra), 6 to 8 feet. 2.50

PLUM, PURPLE (Prunus Othello), 3 to 5 feet. 2.00 POPLAR, NORWAY

6 to 8 feet 
TREES-Continued

POPLAR, BOLLE'S SILVER (Populus alba Bolleana)

8 to 10 feet

10 to 12 feet

Silver leaved, upright in shape, similar to Lombardy.

Common and Botanical Names

Each

Per 10

Per 100

RED BUD (Cercis canadensis)

3 to 4 feet

$\$ 1.00$

\subsection{0}

6 to 8 feet

2.50

8 to 10 feet

3.00

SYCAMORE (Platanus occidentalis)

6 to 8 feet

1.00

8 to 10 feet

1.50

9.00

12.50

12.50

A native variety with white blooms, large scarlet

1.50

in the fall.

THORN, PAUL'S DOUBLE CRIMSON (Crataegus ox-

yacantha Paulii), 3 to 4 feet

The most beautiful of all small flowering trees.

TREE OF HEAVEN (Ailanthus glandulosa)

5 to 6 feet

8 to 10 feet

WALNUT, BLACK (Juglans nigra), 5 to 6 feet

WILLOW, LAUREL LEAVED (Salix pentandra)

4 to 5 feet

1.00

9.00

9.00

WILLOW, GOLDEN (Salix vitellina aurea), 4 to $6 \mathrm{ft}$..... $\mathbf{1 . 0 0}$

9.00

WILLOW, WEEPING (Salix Babylonica), 5 to $6 \mathrm{ft}$....... 1.00

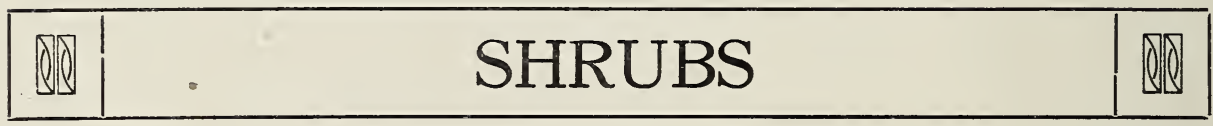

ALMOND, FLOWERING (Prunus glandulosa var'),

ARALIA, PENTAPHYLLA (Fivc-leaved Aralia), 3 to 4 feet.

ARROW-WOOD (Viburnum dentatum), 3 to 4 feet..... 1.00

BARBERRY, JAPANESE (Berberis Thunbergii)

18 to 24 inches

2 to 3 feet

BUTTERFLY BUSH (Buddleia Veitchii), 2 to 3 feet...... 1.00

DOGWOOD, RED TWIGGED (Cornus alba)

DOGWOOD, YELLOW TWIGGED (Cornus stolonifera flaviramea), 2 to 3 feet. 
DOGWOOD, GRAY TWIGGED (Cornus paniculata),

2 to 3 feet

ELDER, AMERICAN (Sambucus canadensis)

2 to 3 feet

6.50

3 to 4 feet

ELEAGNUS, GOUMI TREE (Eleagnus Longipes),

2 to 3 feet

ELEAGNUS, RUSSIAN OLIVE (E. Hortensis Syn. angustifolia)

4 to 5 feet

FORSYTHIA, 3 to 4 feet

8.50

HONEYSUCKLE, MORROWS' (Lonicera Morrowii),

3 to 4 feet

HONEYSUCKLE, Tartarian (Lonicera Tartarica),

HYDRANGEA, PANICULATA GRANDIFLORA,

2 to 3 feet

HYPERICUM AUREUM (Shrubby St. John's Wort),

18 to 24 inch

A small summer yellow flowering shrub.

JAPAN QUINCE (Cydonia Japonica), 3 to 4 feet.

LILAC-TREE (Syringa Pekinensis), 2 to $3 \mathrm{ft}$.

LILAC, PERSIAN (Syringa Persica)

- 2 to 3 feet

3 to 4 feet

LILAC, COMMON PURPLE (Syringa vulgaris)

2 to 3 feet

4 to 5 feet

LILAC, NAMED VARIETIES

2 to 3 feet

ALPHONSE LE VALLE-Double Blue Shaded Violet.

CHARLES X-Single, Reddish Purple.

LA TOUR d'AUVEKGNE-Double, Violet Purple.

LUDWIG SPAETH-Single, Dark Blue.

MADAM LEMOINE-Double White.

MARIE LAGRAYE-Single, White.

MICHEAL BUCHNER-Double, Pale Lilac.

PRES. GREVY-Double, Light Blue. 
LILAC, ROUEN (Syringa Rothomagensis)

Each

$\$ .75$

2 to 3 feet

3 to 4 feet
Per 10

$\$ 6.50$

8.50

8.50

12.50

3 to 4 feet

PHILADELPHUS, DWARF MOCK ORANGE, 2 to $3 \mathrm{ft}$. 1.00

RIBES, ALPINE CURRANT (Ribes alpinum), 18 to 24 inch

ROSE ACACIA (Robinia Hispida), 6 to 8 feet.

ROSES-Named Varieties, No. 1 size

MADAM PLANTIER-Hardy White

HARRISON-Yellow, Hardy

BABY RAMBLER-Crimson

1.00

GRUSS AN TEPLITZ-Red

1.00

FRAU KARL DRUSCHKI-White

SNOWBERRY, WHITE (Symphoricarpos Racemosus)

2 to 3 feet

SNOWBERRY, RED (Symphoricarpos Vulgaris)

2 to 3 feet

SPIREA, ANTHONY WATERER (Pink), 2 to $3 \mathrm{ft} . . .+. . . \$ 1.00$ SPIREA, PRUNIFOLIA (Plumleaf), 2 to 3 feet................. .75

SPIREA, ARGUTA (Early Flowering), 2 to 3 feet...-...... 1.00

SPIREA, VAN HOUTEI (BridaI Wreath)

SPIREA, NINEBARK (Physocarpus Opulifolius)

SUMACH (Rhus Typhina)

3 to 5 feet 
TAMARIX (Gallica), 5 to 6 feet

VIBURNUM, OPULUS (High Bush Cranberry)

2 to 3 feet

VIBURNUM, OPULUS STERILIS (Common Snowball), 2 to 3 feet

VIBURNUM, LANTANA (Wayfaring Tree), 2 to $3 \mathrm{ft} . . . \mathbf{1 . 0 0}$

\section{VINES}

AMPELOPSIS ENGELMANNI (Virginia Creeper which clings to the building), 2-year. $\$ .50$

CELASTRUS ARTICULATUS (Japanese Bittersweet), 2-year

CLEMATIS, PANICULATA (Japanese Sweet Clematis), (White), 2-year

CLEMATIS (Jackmanii) (Blue), 2-year.

TECOMA RADICANS (Trumpet Creeper), 2-year...

LYCIUM CHINESE (Matrimony Vine), 2-year.

WISTERIA MULTIJUGA (Japanese Wisteria), large Howers, 2-year

WISTERIA, SINENSIS (Chinese Purple Wisteria), 2-year

ROSES CLIMBING DOROTHY PERKINS (Pink), 2-year

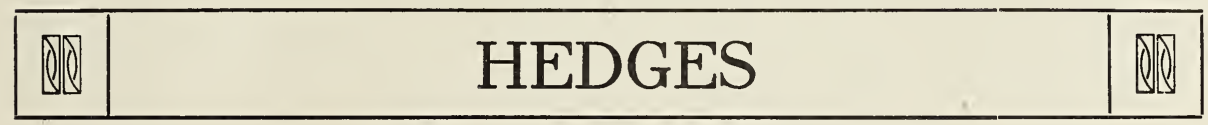

\section{HEDGES-TO BE TRIMNED}

AMOOR RIVER PRIVET (Ligustrum Amurense), 18 to 24 in...\$35.00 in rows.

Plant in double rows 6 inches apart and 8 inches apart

ROUEN LILACS (Rothomagensis)

2 to 3 feet

Plant single row, 18 inches apart. This is undoubtedly the finest of hedges for Nebraska. 
BARBERRY, JAPANESE (Berberis Thunbergii)

18 to 24 inches

2 to 3 feet

ROUEN LILACS (Rothomagensis)

2 to 3 feet

60.00

3 to 4 feet

70.00

PERSIAN LILAC (Syringa Persica)

2 to 3 feet

60.00

3 to 4 feet

70.00

Plant single row 18 inches apart.

SPIREA, VAN HOUTTII,

2 to 3 feet

40.00

3 to 4 feet

60.00

Plant single row 18 inches apart.

\section{Hardy Herbaceous Perennials}

AVALANCHE-It is perfect in form, color milk white, with crimson center, some having faint carmine markings on center petals. Late blooming...\$

CROWN OF GOLD-A compact, solid white, golden reflex, center touchea with carmine. Midseason.

DUCHESS DE NEMOURS-Cup shaped bloom. Large sulphur white. Free flowering

FESTIMA MAXIMA-This is the queen of the whites. A large flower, often 7 inches across. Center flecked with crimson. Early.

LA FIANCEE-A very large, high crown, creamy white, base of petals shaded yellow. Center flecked crimson showing stamen. Midseason......

MIREILLE-Pure white, extra large double, compact and fragrant bloomer. A very choice cut flower

MADAM DE VERNEVILLE-Flowers of exquisite beauty, sulphur white, broad guard petals. Early.

MARIE LEMOINE-Very large, white with yellow shading, touched with pink and chamois tints. An elegant cut flower. Late...

LADY DARTMOUTH-Small, flat, loose rose type. Milk white collar, cream white center flecked with green. Medium height, free bloomer. Early......

BARONESS SCHROEDER-Flesh white, fading to pure white. Globular compact flower of large size. Perfect form. This is one of the most exquisite of Paeonies. Midseason 


\section{HARDY HERBACEOUS PERENNIALS PAEONIES-Continued}

LA TULIP_Very large semi-rose type. Lilac white, fragrant, strong grower and free bloomel. Late midseason..

RED

FELIX CROUSE-Solid, rich, brilliant ruby red. One of the best reds. Midseason

FONTENELLE-Clear brilliant crimson. Full double flower. Extra good . cut flower. Early

KARL ROSENFIELD-Dark Velvety crimson, clear and brilliant without a trace of purple. Strong erect grower, large flower. A most superb red. Early

LA SUBLIME-Free blooming crimson, buds almost black.

MEISSONIER - Full double flowers, brilliant crimson..

MODESTE GUERIN - A very dark bright carmine. Large, compart, bomb shaped flower. Sweetly perfumed. Strong grower and free bloomer. Early

PRESIDENT ROOSEVELT-Fine red. Midseason.

\section{PINKS}

DUCHESS DE ORLEANS-Medium large compact bomb. Guards deep pink. Center shaded salmon with silvery reflex. Fragrant. Midseason..............

EDULIS SUPERBA-The Decoration Day Paeony. Free blooming. Fragrant. Bright pink. Early.

GOLDEN HARVEST - A soft pink, cream and gold. Very popular. Midseason

HUMEI-The cinnamon scented flower. Large flower of bright even pink. Late .

MADAM DE GALHAU-Delicate, glossy pink, tinged flesh and salmon. Sweet and fragrant. Large globular and compact. Late................................

MONS. JULES ELIE-King of Paeonies. Glossy lilac pink with silvery reflex over entire bloom. Early.

OCTAVIE DEMAY - Blush or very light pink, fading to white. Flowers very large, flat and compact. Dwarf grower. Early.

QUEEN EMMA-Very large, full bright pink. Rose type. Grows strong, erect and compact. Midseason....

THERESE-Very large compact bloom. Violet rose changing to lilac white in center. A magnificent Paeony. Midseason...

UMBELLATA ROSEA-Decoration Day Paeony. Earliest of bloomers. Free bloomer. Pretty pink guards shading to amber white. Early............

MADAM LEONIE CALOT-A soft sea shell pink. Tinged a delicate soft lilac. Very free bloomer in clusters and first class cut flower. Midseason

\section{IRIS}

German Iris succeeds in partial shade, but do best in full sun. They will grow anywhere and can be transplanted at almost any season of the year, though best in early Fall or Spring. Plant bud about two inches below surface.

S.-Indicates standard or upright petals.

F.-Indicates falls or drooping petals.

ATROPURPUREA-S. and F. Rich claret purple.......................................................\$ .15

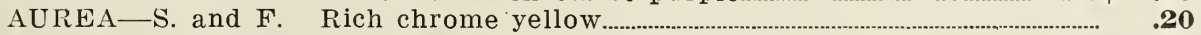

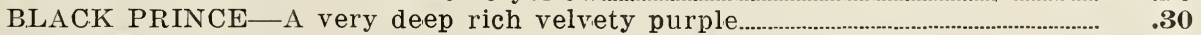

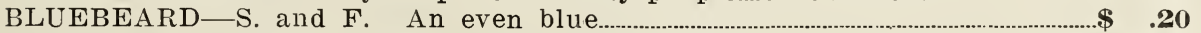

CAPRICE-S. Reddish purple. F. Deeper purple

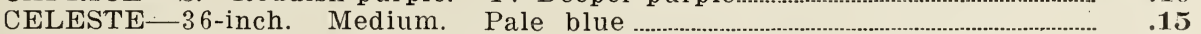

CHALCEDONIA - 30-inch. Medium. S.-Light mauve. F.-Purple, heavily veined

DARIUS-18-inch. Medium. S.-Primrose yellow. F.-Lilac with primrose margin

DR. BERNICE-Coppery bronze and velvety crimson. 


\section{IRIS-Continued}

ELIZABETH-30-inch. S.-Pale lavendar. F.-Mauve

ELDORADO-S.-Yellowish bronze shaded with heliotrope. F.-Bright purple touched with bronze yellow.

ELEGANS-30-inch. Nedium. S.-Nearly white, dashed with violet. F.-Violet, veined white.

EUGENE-SUE-20-inch. Medium. S.-White. F.-Violet with white edge

RY-36-inch. Medium. S.-White. F.-White, harmingly veined.
Peach blossom odor Peach blossom odor.

FLORENTINA ALBA-30-inch. Very early. S.-White. F.-Porcelain, changing to white

GRACCUS-24-inch. Medium. S.-Light yellow. F.-Yellow veined with purple. Fragrant

GYPSY QUEEN-24-inch. Late. S.-Old gold, shaded smoked pearl. F. -Maroon reticulated light yellow.

HER MAJESTY-32-inch. Late. S.-Soft rose. F.-Red, deeply veined... INNOCENZA-24-inch. Medium. S. and F.-Ivory white...

ISOLINE-S.-Lilac pink. F.-Purplish old rose with golden throat and yellow beard

JACQUESIANA - 36-inch. Late. S.-Coppery crimson. F.-Rich maroon KHEDIVE-30-inch. Medium. Pretty lavendar flowers........................................

KING OF IRISES-24-inch. Medium. S.-Fawn yellow. F.- Velvety crimson with distinct heavy margin

LEONIDAS - 30-inch. Late. S.-Violet blue. F.-Rich velvety purple...... LORELLY - 24-inch. Medium. S.-Golden sprinkled madder. F.-Purple MADAM CHEREAU-40-inch. Medium. Flowers white, frilled with violet MRS. H. DARWIN-30-inch. Late. S.-Pure white. F.-White, fiinely reticulated

MRS. NEUBRONNER-26-inch. Medium. Rich golden yellow. Combines well with Oriental Poppy.

MADAM BLANCHE PION-S.-Pale bronze yellow, shot with lavendar. F.-Rich purple

MISS WILLMOT-Very fine white. Often washed with lavendar..

MADAM PACQUETTE-30-inch. Medium. Rosy claret...

MONSIGNOR-24-inch. Late. S.-Rich satiny violet. F.-Velvety purpls crimson

OSSIAN-30-inch. Medium. S.-Canary yellow. F.-Light claret red........

PALIDA-ASTARTE-36-inch. Late. S.-Rosy lilac. F.-Blue.

PARISIANNA - S.- White dotted light purple. F.-White, frilled at edge with purple

PERFECTION-30-inch. Medium. S.-Blue. F.-Dark velvety purple with charming reflex...

PRINCESS VICTORIA LOUISE-30-inch. Medium. S.-Pure sulphur yellow. F.-Rich plum with cream colored edges

QUEEN OF MAY - 30-inch. Early. Rose lilac. General cast, pink.

RHEIN NIXE-36-inch. Late. S.-White. F.-Deep violet blue, white margin

ROSE UNIQUE-30-inch. Early to medium. Deep pink

SAMBUCIANA BEETHOVEN-24-inch. Medium. S.-Lilac, finely reticulated. F.-Rosy purple, orange crest.

SANS SOUCI-24-inch. Late. S.-Golden. F.-Mahogany red

HALFDAN-18-inch. Very early. S and F.-Creamy white................................

WALHALLA - 20-inch. Very early. S.-Light sky blue. F.-Violet purple

\section{BEARDLESS IRIS}

LONGIPETELLA - 36-inch. Late. Soft porcelain blue 


\section{hARDY HERBACEOUS PERENNIALS}

\section{SIBERIAN IRIS}

SIBERIAN BLUE

SNOW QUEEN - Large white flowers, with golden throat............................................ . .20

\section{PHLOX}

Culture.-Keep the soil moist and loose around the phlox. Water heavily during the hot season. Mulch heavily during the Winter.

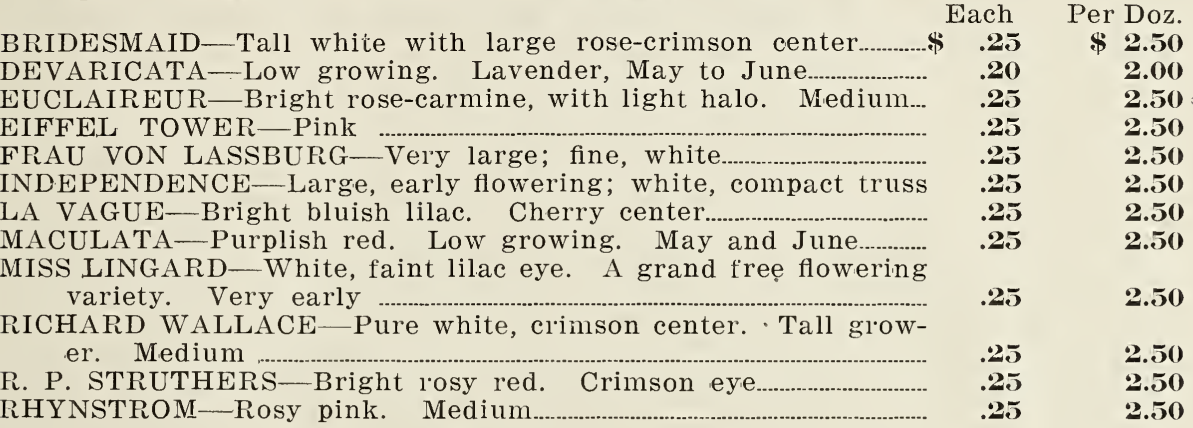

\section{O'THER PERENNIALS}

\section{Common and Botanical Name.}

ALTHEA ROSEA (Hollyhock) - July and August-4 to 6 feet. Mixed colors

Per Doz.

ANTHEMIS TINCTORIA (Marguerite)-Yellow-2 to 3 feet. July to October

AQUILEGIA (Columbine)-Blue to pink-2 to 3 feet. May to June

ASCLEPIAS TUBEROSA (Butterfly Weed)-Orange-2 to $3 \mathrm{ft}$. July and August

ASTER CLIMAX - Large, bright violet flowers, 2 inches in diameter with prominent golden centered disk -5 feet. October...

ASTER NOVA ANGLAE-Varying shades of rich violet purple -4 feet. October

ASTER MRS. RAYNER-Crimson-5 feet. September

ASTER ROBT. PARKER-Lavender-4 feet. September and Octobel'

ASTER ST. EGWYN-Soft pink-3 feet. September and October

BOLTONIA LATISQUAMAE (False Chamomile)-Pink-6 to 8 feet. August and September.

CHRYSANTHEMUM, POMPOMS-Mixed-2 to 3 feet. November

CLEMATIS, DAVIDIANA (Shrubby Clematis)-Blue-2 to 3 feet. July and August..

COREOPSIS GRANDIFLORA-Yellow-2 to 3 feet. July to October

DELPHINIUM FORMOSUM-Blue-3 to 6 feet. June to Sept.

DIANTHUS BARBATUS fl. pl. (Double Sweet William)-Mixed. 12 inches. May and June.

ECHINACEA PURPUREA (Cone Flower) - Reddish purple-3 to 5 feet. July to September..

EUPATORIUM AGERATOIDES (White Snake Root) - White.

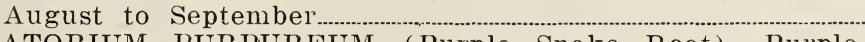

EUPATORIUM PURPUREUM (Purple Snake Root)-Purple. August to September. 
FUNKIA COERULEA (Plantain Lily)-Blue, 2 feet. August and September. Grows in dense shade.

Each

Per Doz.

GAILLARDIA-Red yellow, 2 to 3 feet. July to October......................

HELENIUM AUTUMNALE SUPERBUM (Sneeze Weed)-Yellow, 4 to 5 feet. August and September

HELENIUM RUBRUM (Sneeze Weed)-Red, September and October -4 to 5 feet.

HELIOPSIS PITCHERIANA (Orange Sunflower)-Orange, 4 to 5 feet. July to. November.

HEMEROCALLIS APRICOT (Day Lily)-Apricot, 2 feet. June HEMEROCALLIS DUMORTIERI-Orange, 1 foot. May................. HEMEROCALLIS FLAVA-Lemon, $2 \frac{1}{2}$ feet. June..

HEMEROCALLIS JULIA-Bronze, 3 feet. August.

HEMEROCALLIS MIDDENDORFII-Orange, 1 to 2 feet. June

HEMEROCALLIS THUNBERGII-Lemon yellow, 2 to 3 feet. July and August

HIBISCUS MALLOW MARVELS-Mixed, 3 to 4 feet. July and August

LIATRIS PYCONSTACHYA (Blazing Star)-Purple, 4 feet. August and September..

LYSIMACHIA NUMMULARIA (Loose Strife)-Yellow. June. A ground cover for shady places.

MONARDA DIDYMA (Oswega Tea)-Red, 3 feet. July to Sept.

PARDANTHUS CHINENSIS (Blackberry Lily)-Orange, 3 feet. July

PAPAVER ORIENTALE (Oriental Poppy)-Orange to scarlet, 2 to 3 feet. June.

PHYSOSTEGIA VIRGINIANA (False Dragon Head)-Deep rose to lilac, 3 feet. August.

PLATYCODEN GRANDIFLORA (Chinese Bell Flower)-Blue, 2 feet. July and August

PYRETHRUM ROSEUM (Painted Daisy) - Various, 2 to 3 feet. May and June.

PYRETHRUM ULIGINOSUM (Ox-Eyed Daisy) - White, 4 to 5 feet. September

RUDBECKIA AUTUMN GLOW-Orange, 5 feet. August and September

RUDBECKIA NEWMANNI-Orange, 3 feet. July and August

SAPONARIA (Soap Weed)-Pink. May to August, 2 feet.

SEDUM SPECTABILIS (Stone Crop)-Brilliant crimson, 1 to 2 feet. July and August. Will grow in the dryest season.........

THALICTRUM (Meadow Rue) - White, 3 to 4 feet. June..............

VERONICA SPICATA (Speedwell)-Blue, 2 feet. June to Aug.

VERONICA SPICATA (Sjeedwell)-Blue, 2 feet. June to Aug.

VINCA MINOR (Common Periwinkle or Trailing Myrtle)Trailing evergreen ground cover. Especially for shade..........

YUCCA (Spanish Bayonet)-White, 6 feet. June and July. Foliage evergreen

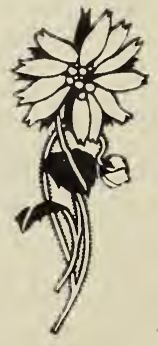



